Canadian

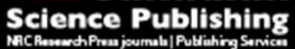

Canadian Journal of Microbiology Revue canadienne de de microbiologie

\title{
Influence of Wave Action on the Partitioning and Transport of Unattached and Floc-Associated Bacteria in Freshwater
}

\begin{tabular}{|r|l|}
\hline Journal: & Canadian Journal of Microbiology \\
\hline Manuscript ID: & cjm-2014-0815.R2 \\
\hline Manuscript Type: & Article \\
\hline Date Submitted by the Author: & O8-Jun-2015 \\
\hline Complete List of Authors: & $\begin{array}{l}\text { Sousa, Andrew J.; Ryerson University, Department of Chemistry and } \\
\text { Biology } \\
\text { Droppo, Ian; Environment Canada, Water Science and Technology } \\
\text { Directorate } \\
\text { Liss, Steven N.; Queens University, Department of Chemical Engineering } \\
\text { Warren, Lesley; McMaster University, School of Geography and Earth } \\
\text { Sciences } \\
\text { Wolfaardt, Gideon; Ryerson University, }\end{array}$ \\
\hline Keyword: & bacteria, sediment bacteria, floc, wave action, bacterial mobilization \\
\hline
\end{tabular}




\section{Influence of Wave Action on the Partitioning and Transport of Unattached and Floc-Associated Bacteria in Freshwater}

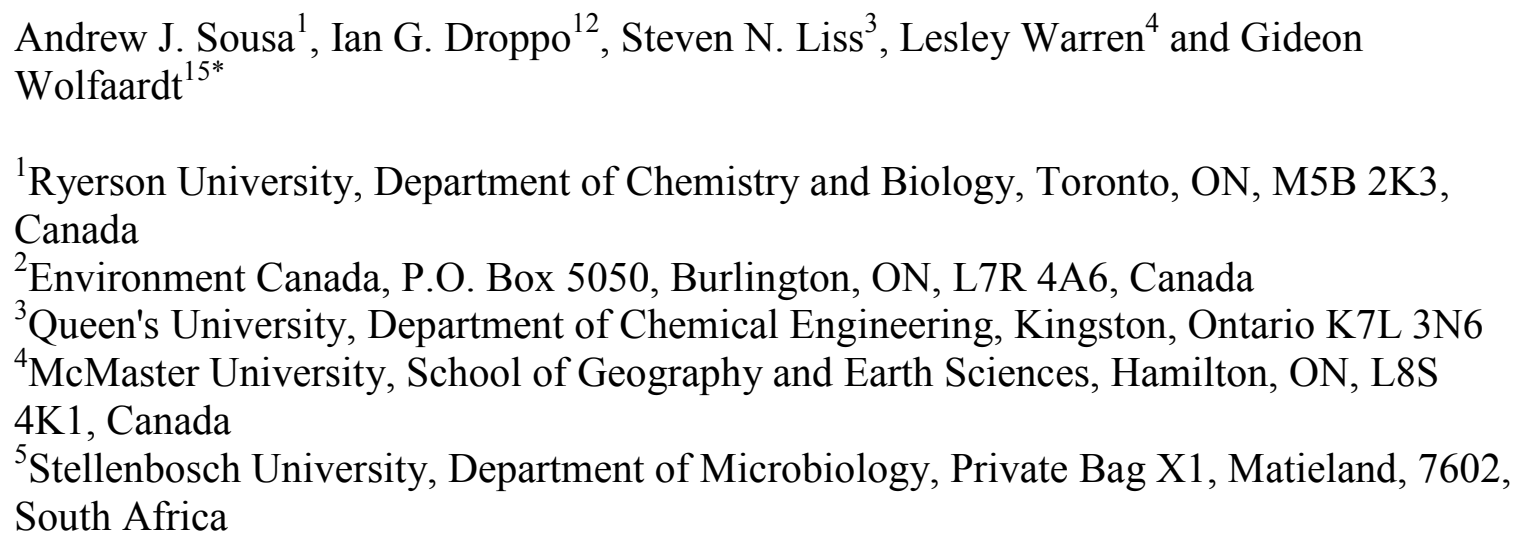


46 Abstract: The dynamic interaction of bacteria within bed and suspended sediment/floc in

47 a wave dominated beach environment is assessed using a laboratory wave flume. The

48 influence of shear stress (wave energy) on bacterial concentrations, and the partitioning

49 and transport of unattached and floc-associated bacteria is investigated. The study

50 showed that increasing wave energy $(0.60$ and $5.35 \mathrm{~N} / \mathrm{s})$ resulted in a 0.5 to $1.5 \log$

51 increase in unattached cells of the test bacterium Pseudomonas sp. strain CTO7::gfp-2 in

52 the water column. There was a positive correlation between the bacterial concentrations

53 in water and total suspended solids, with the latter increasing from near zero values up to

$54200 \mathrm{mg} / \mathrm{L}$ over the same wave energy increase. The median equivalent spherical diameter

55 of flocs in suspension also increased by an order of magnitude in all experimental trials.

56 Under both low $(0.60 \mathrm{~N} / \mathrm{s})$ and high $(5.35 \mathrm{~N} / \mathrm{s})$ energy regime, bacteria were shown to

57 preferentially associate with flocs upon cessation of wave activity. The results suggest

58 that collection of water samples during periods of low wave action for the purpose of

59 monitoring the microbiological quality of water may underestimate bacterial

60 concentrations, due in part to an inability to account for the effect of shear stress on the

61 erosion and mobilization of bacteria from bed sediment to the water column. This

62 highlights the need to develop a more comprehensive beach analysis strategy that not

63 only addresses presently uncharacterized shores and sediments, but also recognizes the

64 importance of eroded floc as a vector for the transport of bacteria in aquatic

65 environments.

66

67

68 Key words: Bacteria, floc, sediment bacteria, wave action, bacterial mobilization 


\section{Introduction}

Monitoring the microbiological quality of recreational water is vital for assessing

75 the human health risk at public beaches. Pathogenic bacteria can be introduced to

76 freshwater from a variety of point sources such as combined and sanitary sewer

77 overflows (Perdek 2003) and nonpoint sources such as stormwater runoff and fecal

78 droppings from wildlife (Kinzelman et al. 2004; Craun et al. 2005; Ji 2008). In order to

79 characterize the public health risk associated with contaminated sands and sediments,

80 public health units typically collect only whole water samples with the assumption that

81 planktonic cells represent the total bacterial community present in beach environments.

82 This practice may underestimate potential sedimentary sources of pathogens, which have

83 been shown to be temporal sinks and sources of bacteria to the water column (Ishii et al.

84 2007), and the ecological importance of floc on the erosion, transport and delivery of

85 bacteria in aquatic environments (Droppo et al. 2009; 2011).

86 Flocs found within the water column are composed of a viable and non-viable

87 biological component, inorganic particles, and water. The development of these flocs is

88 dependent on interacting biological, physical, and chemical properties including

89 dissolved organic matter, surface charge, hydrophobicity, $\mathrm{pH}$, redox potential, turbulence,

90 and suspended solids (Droppo et al. 1997). One abiotic phenomenon, electrochemical

91 flocculation, is influenced by the net surface charge of a particle, expressed as zeta

92 potential, resulting in attraction or flocculation due to the reduction of the electrochemical

93 double layer. This double layer is created when flocs imparting a net negative surface

94 charge interact with positive cations in solution that electrically screen the surface charge 
95 and allow for the association of negatively charged particles (including bacteria).

96 Bioflocculation is influenced by the metabolic action of microorganisms leading to the

97 production of extracellular polymeric substances (EPS) and the "sticking" together of

98 flocs (Gerbersdorf and Wierpecht 2014). In reality, electrochemical and bioflocculation

99 occur simultaneously, however, it is generally accepted that the latter dominates

100 flocculation of particles in the freshwater environment (Droppo et al. 2009). The net

101 effect of flocculation is to increase the downward flux of particles, thus facilitating the

102 transport of bacteria from the overlying water column to the lake bed (Wu et al. 2009).

103 Concomitant with floc deposition on the bed sediment is the incorporation and

104 persistence of the floc associated bacteria into the bed biofilm. Biofilms represent a

105 mixed community of microorganisms bound to a surface and encased in an exopolymeric

106 matrix (Cogan et al. 2011). Within a sand dominated bed such as a beach environment, a

107 variety of niches that allow for biofilm assembly are available given the large surface

108 area of sand grains, interstitial voids between grains, and microhabitats that are created by

109 variable surface topography. Bacteria can exploit these niches for growth and survival

110 (Bonilla et al. 2007), and protection from predation (Hartz et al. 2008). There is potential

111 for sediment-associated biofilms to assimilate, and subsequently act as a source of

112 bacteria to the water column through re-suspension caused by shear stress due to wave

113 action, disturbance of sediments by swimmers (Brookes et al. 2004), or biofilm-to-

114 planktonic yield (Bester et al. 2009; 2010; Ghadakpour et al. 2014).

115 Wave action has been suggested as a potential mechanism of bacterial re-

116 suspension in water (McLellan and Salmore, 2003; Petersen et al. 2005) and foreshore

117 sand (Ishii et al. 2007, Whitman et al. 2003). However few studies have attempted to 
118 measure the contribution of wave energy to elevated levels of bacteria in water

119 (Kinzelman et al. 2004), partly because the interpretation of data from field studies is

120 difficult due to a large number of overlapping physicochemical, biotic and abiotic factors

121 that influence bacterial mobilization, as well as growth and decay kinetics, as indicated

122 by Dette et al. (2002).

123 The goal of the present study was to assess the effect of shear stress imparted by

124 wave action on bacterial concentrations in sediments and the water column, as well as the

125 partitioning and transport of unattached and floc-associated bacteria by utilizing a wave

126 flume (mesocosm) and an environmental test bacterial strain.

\section{Materials and methods}

\section{Flume design}

130 A linear flume was used to subject a meso-scale beach model to waves of variable height

131 (Figure 1). The system, described in detail by Droppo et al. (2007) measured $13 \mathrm{~m}$ in

132 length, $0.3 \mathrm{~m}$ in width and $0.5 \mathrm{~m}$ in height. The test area was the wash zone, separated

133 from the rest of the flume by a flexible non-permeable wave energy transmitting

134 membrane (WETM). The WETM allowed energy (waves) rather than materials to pass

135 through the propagation channel to the $1.6 \mathrm{~m}$ long wash zone; thus containing introduced

136 test bacteria in a relatively small volume. The wash zone contained a constructed beach

137 with a 1:10 slope and maximum water depth of $15 \mathrm{~cm}$. One $\mathrm{Hz}$ sinusoidal waves of 2, 4

138 and $6 \mathrm{~cm}$ were generated at the end opposite of the wash zone using a wave paddle

139 oscillator. Wave height was monitored using calibrated wave staffs (converts voltage to

140 wave height) positioned on each side of the WETM. 


\section{Inoculum, beach sand, and water}

145 Pseudomonas sp. strain CTO7::gfp-2 (DQ777633) was used to track bacterial transport in

146 all experiments. While other strains have been used in studies of bacterial sediment

147 interactions, we were interested in the ability of Pseudomonas strains to form aggregates

148 such as biofilms within various aquatic environments (see e.g., Tolker-Nielsen et al.

149 2000; Sauer et al. 2002, Purevdorj-Gage et al. 2005) where they create

150 microenvironments in which other strains, including pathogens, can persist and

151 proliferate, and thereby extend their habitat range. The inoculum was grown in $500 \mathrm{~mL}$ of

152 sterile $3 \mathrm{~g} / \mathrm{L}$ tryptic soy broth (EMD Biosciences) for $15 \mathrm{~h}$ in a tabletop shaking incubator

$153(250 \mathrm{r} / \mathrm{min})$ at $30^{\circ} \mathrm{C}$. The stable and site-specific chromosomal insertion of green

154 fluorescent protein (GFP) was verified previously using PCR and growth curve analysis

155 (Bester et al. 2009; Wolfaardt et al. 2008). Previous studies also demonstrated the ability

156 of the strain to form biofilms on such surfaces as Plexiglas, borosilicate glass and silicon

157 (Kroukamp and Wolfaardt 2009; Bester et al. 2009; 2010). Beach sand was obtained from

158 the swash zone at the Sunnyside Beach of Lake Ontario, Toronto, Canada, and was used

159 without sterilization for experiments that examined the effect of shear stress on the

160 partitioning of unattached and floc-associated bacteria, as well as bacterial concentrations

161 in water. This sediment was selected since Sunnyside Beach has to be closed for up to

$16269 \%$ of the swimming season due to high levels of E. coli (City of Toronto 2009). Lake 
163 Ontario water was used in the wash zone (experimental area), while dechlorinated tap

164 water was used for wave propagation to the WETM from the wave paddle.

\section{Transport of bacteria in beach sand}

168 To assess bacterial transport through sand, the beach was formed using well-

169 characterized, commercially available sand (Ottawa sand; Bell and Mackenzie Co. Ltd.,

170 Hamilton, Canada), consisting of $99.88 \% \mathrm{SiO}_{2}, 0.015 \% \mathrm{Fe}_{2} \mathrm{O}_{3}, 0.050 \% \mathrm{Al}_{2} \mathrm{O}_{3}, 0.010 \%$

$171 \mathrm{CaO}, 0.003 \% \mathrm{MgO}, 0.003 \% \mathrm{~K}_{2} \mathrm{O}, 0.007 \% \mathrm{Na}_{2} \mathrm{O}$, and $0.1 \%$ clay and silt. Screen analysis

172 provided by the manufacturer stated that $62 \%$ of the particles passed through a 70 -mesh

173 sieve (particles smaller than $0.210 \mathrm{~mm}$ ). These characteristics were chosen based on the

174 average grain size of the Sunnyside Beach sand. Eighty L of Lake Ontario water was

175 mixed with $10^{9}$ cells (total viable count) of the test strain and carefully siphoned into the

176 test area in order to cause minimum disruption of the sand profile. The flume was left

177 with no wave action for 24 hours, after which sterile syringes were used to core $6 \mathrm{~cm}$ into

178 the sediment along five transects (Figure 2B). Cores were divided into three $2 \mathrm{~cm}$

179 sections and labelled top (upper $2 \mathrm{~cm}$ of the sediment bed; sediment/water or air

180 interface), middle and bottom (lower $2 \mathrm{~cm}$ of sediment). Viable cell counts of the

181 sediment samples were then determined to assess microbial migration through sand.

\section{Influence of shear on in-bed sediment bacterial distribution and erosion}

184 Approximately $120 \mathrm{~L}$ of saturated beach sediment was homogenized with $10^{9}$ cells (total

185 cell count) of the test strain using a rotating mixer. The inoculated sediment was left to 
186 stand for 72 hours at room temperature $\left(22 \pm 2{ }^{\circ} \mathrm{C}\right)$ to allow for the test strain to become

187 associated with the particles in the sediment. The sediment bacteria mixture was then re-

188 homogenized and laid down in the wash zone of the flume to form the beach (Figure 1).

189 Sand core samples were taken (see below) to verify that there was a uniform distribution

190 of the test organism within the sediment.

191 Hamilton Harbour water was collected and stored at $4{ }^{\circ} \mathrm{C}$ until use in the flume.

192 The water was equalized to room temperature before it was added to the flume without

193 sterilization. Once the sediment was laid down in the flume, $80 \mathrm{~L}$ of Hamilton Harbour

194 water was carefully siphoned into the wash zone to minimize disturbance of inoculated

195 sediment. Dechlorinated tap water was added to the propagation channel and the system

196 was left for one hour.

197 To assess the effect of shear stress on bacterial concentrations in water, the flume

198 was sequentially operated for one-hour intervals at 2, 4, and $6 \mathrm{~cm}$ wave heights. This

199 procedure is analogous to an annular flume test where bed shear stress is increased

200 sequentially to simulate a hydrograph. While this results in a cumulative effect, it does

201 allow for the assessment of a dynamic storm event given that environmental conditions

202 will always be changing. Experiments with consistent wave energy were also performed

203 and are described below. As shear stress is difficult to determine in a wave-breaking

204 environment, a wave energy flux (in Newton per second) was used to represent a measure

205 of shear as described by Turker and Kabdash (2006). Wave heights of 2, 4, and $6 \mathrm{~cm}$ with

206 a $15 \mathrm{~cm}$ water depth were equivalent to a wave energy flux of $0.60,2.38$, and $5.35 \mathrm{~N} / \mathrm{s}$,

207 respectively. At the end of every wave height, sterile $10 \mathrm{~mL}$ syringes (BD Biosciences)

208 with the front tip cut off were used to core, in duplicate, $6 \mathrm{~cm}$ deep into the sediment 
209 along four transects (T1 - T4; Figure 2A). Triplicate water samples were collected in 15

$210 \mathrm{~mL}$ polypropylene tubes (BD Biosciences) every 15 minutes in the wave-breaking zone

211 to determine culturable cell counts. Duplicate $50 \mathrm{~mL}$ water samples were collected to

212 determine suspended sediment concentration by filtration under vacuum through pre-

213 dried and tared $0.45 \mu \mathrm{m}$ filters (Millipore). Plankton chambers were filled after every

214 wave height for visualization of flocs and determination of particle size distribution using

215 a combination of microscopy, photography, and image analysis (Droppo et al. 1997).

216 Four separate trials were conducted.

217 In order to verify that there was no significant growth of the test strain during the

218 three hour time period of wave action, triplicate flasks were packed with inoculated

219 sediment, and $50 \mathrm{~mL}$ of Hamilton Harbour water was added on top. The flask was left to

220 sit for 1 hour to equilibrate and allow cells to move into the aqueous phase. Flasks were

221 then placed in a benchtop shaker $\left(200 \mathrm{rpm} ; 22^{\circ} \mathrm{C}\right)$ and shaken for 3 hours. Samples were

222 taken every 30 minutes, which demonstrated a steady test strain count in water at around

$2235.2 \log$ over 3 hours.

226 Comparison of low and high wave energy flux to evaluate partitioning of unattached

227 and floc-associated bacteria

228 The beach was prepared as previously described, and in two separate experiments the

229 flume was operated with 2 and $6 \mathrm{~cm}$ wave heights $(0.60$ and $5.35 \mathrm{~N} / \mathrm{s})$ to assess the effect

230 of shear strength on the partitioning of unattached and floc-associated bacteria in the

231 water column. For each of these wave heights, the initial one-hour equilibration period 
232 was followed by $4 \mathrm{~h}$ of continuous wave activity followed by $2.5 \mathrm{~h}$ of no wave activity to

233 investigate the influence of settling dynamics on the partitioning of bacteria. Sediment

234 core samples were collected with sterile $10 \mathrm{~mL}$ syringes with the front tip cut off as

235 described above, and an additional $50 \mathrm{~mL}$ water sample was collected for enumeration of

236 unattached and floc-associated fractions. In addition to the analyses done in plankton

237 chambers, a CILAS 930 particle size analyzer (CILAS, Orleans, France) was used for

238 real-time measurements of median equivalent spherical diameter $\left(\mathrm{d}_{50}\right)$ in the 0.2 to 500

$239 \mu \mathrm{m}$ diameter range.

242 Enumeration of test strain

\section{Core Samples}

244 Each core sample was sectioned into $2 \mathrm{~cm}$ aliquots and serial dilutions prepared in $0.9 \%$

$245(\mathrm{~m} / \mathrm{v})$ sterile buffered saline followed by spread plating on $3 \mathrm{~g} / \mathrm{L}$ tryptic soy broth with

$2461.5 \%(\mathrm{~m} / \mathrm{v})$ agar for routine enumeration of the test strain. After incubation at $30^{\circ} \mathrm{C}$ for 24

$247 \mathrm{~h}$, colonies were screened for gfp fluorescence using a fluorescence dissection

248 microscope (Leica). Bacteria were removed from sand grains by vortexing $1 \mathrm{~g}$ of sand

249 with $0.5 \mathrm{~mL}$ of $0.9 \%(\mathrm{~m} / \mathrm{v})$ sterile buffered saline for 30 seconds (corresponded to

250 approximately $80 \%$ cell removal; data not shown).

252 Water Samples

253 To separate bacteria into unattached and floc-associated fractions, $50 \mathrm{~mL}$ water samples

254 were passed through $5 \mu \mathrm{m}$ cellulose acetate filters (Sterlitech). Cellulose acetate filters 
255 were chosen because they offered low binding of microorganisms (BSA protein binding

256 of $3.8 \mu \mathrm{g} / \mathrm{cm}^{2}$ ). A previous study found that selective size filtration was useful for the

257 estimation of particle-associated E. coli in river water (Alm et al. 2006). Bacteria in the

258 filtrate were considered unattached, while bacteria that remained on the filter were

259 considered floc-associated. Both fractions were subjected to ultrasonication $(35 \mathrm{kHz})$ for

2601 minute (optimal time that maximized floc break up and minimized cell death; data not

261 shown). Samples were then diluted in $0.9 \%(\mathrm{~m} / \mathrm{v})$ sterile buffered saline, filtered through

$2620.45 \mu \mathrm{m}$ polycarbonate filters (Pall Corporation), plated, and screened as described

263 previously. $\log _{10}$ transformations were applied to all bacterial counts to normalize data.

265 Visualization of bacteria associated with sand grains and eroded floc

266 To visualize biofilm development on sand grains, biofilms were cultivated in a

267 continuous flow cell made from Plexiglas (dimensions of $30 \mathrm{~mm} \times 6 \mathrm{~mm} \times 60 \mathrm{~mm}$ ).

268 Sediment from Sunnyside Beach was placed in the flow cell, which was irrigated with

269 Lake Ontario water supplemented with $0.3 \mathrm{~g} / \mathrm{L}$ tryptic soy broth. To prevent movement of

270 sand grains into waste and medium reservoirs, small-pore mesh was glued at connection

271 ports. The flow cell was aseptically inoculated upstream using a sterile needle and

272 syringe with $100 \mu \mathrm{L}\left(10^{6}\right.$ cells $)$ of a culture of Pseudomonas sp. strain CTO7::gfp-2 that

273 was previously cultured in a shaking incubator $\left(0.3 \mathrm{~g} / \mathrm{L}\right.$ tryptic soy broth, $30^{\circ} \mathrm{C}, 250$

$274 \mathrm{r} / \mathrm{min})$. The inoculated bacteria were allowed to adhere for $0.5 \mathrm{~h}$ under quiescent

275 conditions, where after a medium flow rate of $5 \mathrm{~mL} / \mathrm{h}$ was initiated with a Watson-

276 Marlow 205S peristaltic pump. Biofilms were allowed to develop for 72 hours, then

277 visualized using an LSM 510 confocal laser scanning microscope (CLSM; Carl Zeiss, 
278 Ontario, Canada). Excitation with a $488 \mathrm{~nm}$ Ar laser line (15\% output) and emission with

279 a band pass filter setting of 500-550 $\mathrm{nm}$ were used to visualize the test strain.

\section{$281 \quad$ Results}

282

\section{Movement of bacteria through sand}

284 The test strain was present throughout the flume beach after adding Hamilton Harbour 285 water containing the test strain, and left for 24 hours without wave action. The highest 286 concentration of bacteria was found at the water line (shoreline, transect 3; see Figure 287 2B), while the presence of bacteria along transects 4 and 5, which lay above the water 288 line and water table, respectively, indicated that cells moved along a wet to dry gradient 289 (beyond the shoreline) potentially by capillary action (Figure 3A). The distribution of

290 cells was highly variable for all transects. The 1 to 3 log increase in bacterial levels $(\sim 8.3$

$291 \times 10^{3}$ cells $/ \mathrm{mL}$ wet weight) in sediment can be attributed to the growth and association of 292 the test organism during the initial 72 hour incubation period.

\section{Sand biofilms}

295 Visualization of unstained floc samples with CLSM, and TSA plates with a fluorescence

296 dissection microscope containing indigenous microbial communities of Lake Ontario

297 water and Sunnyside Beach sand, confirmed the absence of auto-fluorescence and thus

298 the usefulness of the GFP-tagged test strain (data not shown). Figure 3B shows a

299 Sunnyside Beach 72-hour sand biofilm formed by the test strain and indigenous bacteria

300 within the continuous flow cell and CLSM imaging. 


\section{Effect of shear on bacterial concentrations in water}

305 There appeared to be a strong correlation between wave energy, total suspended solids

306 (TSS), floc median equivalent spherical diameter $\left(\mathrm{d}_{50}\right)$ and numbers of the test strain

307 (Figure 4, Table 3). Numbers of the test strain increased between $0.5 \log$ (Figures 4a, b,

308 d) and $1.5 \log$ (Figure 4C) with increasing wave energy flux. Total suspended solids

309 concentration also increased over the same wave energy flux range reaching

310 approximately $200 \mathrm{mg} / \mathrm{L}$ in all cases except for trial 4 (Figure 4D; 120 mg/L). The $\mathrm{d}_{50}$

311 of flocs in suspension also increased by an order of magnitude in all trials with increasing

312 wave energy. The increase in floc size may have been due to flocculation in the water

313 column, and/or the re-suspension of larger particles with increasing wave energy. It

314 should be noted that for trials 1 (Figure 4A) and 4 (Figure 4D) the $\mathrm{d}_{50}$ decreased at the

315 highest wave energy flux, which may be reflective of higher turbulence resulting in floc

316 breakage. The breaking of flocs at high wave energy may also be attributed to the

317 composition of the sediment, as it was collected at different times as the project

318 proceeded and thus may have varied in the composition of the cohesive fraction (silts and 319 clays).

\section{Effect of increasing shear on bacterial distribution in the sediment bed}

322 The redistribution and winnowing of the test bacterial strain from the sediment bed was

323 seen along three out of four beach transects. Transects corresponding to the wave

324 breaking zone and swash zone show that increasing wave energy flux generally led to the 
325 loss of the test organism from the bed sediment (Figure $\mathbf{5 A}, \mathbf{B}, \mathbf{C}$ ) at the higher wave

326 energy flux values. This effect was most prominent for the top core section (top $2 \mathrm{~cm}$ of

327 the sediment bed), which correlates with visual observations that confirm this section as

328 the most dynamic. Transect 1 , which corresponded to the wave-breaking zone, showed a

329 decrease in the numbers of test organism with increasing wave energy for the bottom,

330 middle and top cores. The transect that corresponded to the far upshore region of the

331 beach (T4) did not come into contact with the water table or swash and consequently did

332 not have erosion of the test strain from the top core section. The bottom section of this

333 core did however show a decrease in the numbers of test organism during wave events.

335 Partitioning of unattached and floc-associated bacteria under low $(0.60 \mathrm{~N} / \mathrm{s})$ and 336 high (5.38 N/s) wave energy flux

337 When water samples were partitioned into unattached and floc-associated fractions using

338 selective size filtration, it was found that the viable cell count for both phases did not

339 change substantially during the 4 hours of wave activity at $0.60 \mathrm{~N} / \mathrm{s}$ (Table 1 ). It is

340 interesting to note, however, that there was a higher concentration of the test organism

341 attached to surfaces, with cell counts being one to two orders of magnitude greater than

342 for the unattached phase per $50 \mathrm{ml}$ of sample. When waves were turned off, there was an

343 order of magnitude increase in the number of floc-associated cells per mg of floc

344 material, even though the suspended sediment concentration was reduced by

345 approximately $20 \%$ after just 30 minutes of settling. The median equivalent spherical

346 diameter gradually decreased from 17 to $5 \mu \mathrm{m}$ over the period of wave activity, which

347 indicated that larger flocs were settling out of the water column under this condition. This 
348 is substantiated by the gradual reduction in TSS during the wave period (Table 1). After

349 an additional 2.5 hours of quiescent settling, the floc size further decreased to $2.6 \mu \mathrm{m}$. It

350 is unlikely that floc breakage was occurring during the quiescent settling period.

351 Similar to what was observed for a wave energy flux of $0.60 \mathrm{~N} / \mathrm{s}$, the viable

352 unattached and floc-associated cell counts did not vary significantly during the 4 hours of

353 wave activity at $5.35 \mathrm{~N} / \mathrm{s}$ (Table 2). The total suspended solids concentration decreased

354 by roughly half when waves were shut off, and the number of floc-associated cells per

$355 \mathrm{mg}$ of floc material also increased by an order of magnitude. In contrast to the $0.60 \mathrm{~N} / \mathrm{s}$

356 shear, the median floc equivalent spherical diameter reduced initially, but then remained

357 consistent at around $10 \mu \mathrm{m}$ for the duration of wave activity. During the quiescent

358 period, floc size gradually decreased, but only down to $7.75 \mu \mathrm{m}$ in size. It is likely that

359 higher wave energy flux prevented larger flocs from settling to the sediment bed and

360 resulted in an equilibrium floc size carrying capacity of around $10 \mu \mathrm{m}$. This equilibrium

361 floc size was maintained even though there was a gradual increase in TSS during the

362 wave period (Table 2). Bacteria that are preferentially attached to larger flocs are

363 removed from the water column by the downward flux of these particles.

\section{Discussion}

366 The effect of wave energy flux on bacterial distribution between the sediment and

367 aqueous phases highlights the relevance of microbial behaviour and/or dynamics to

368 public health, as it appears probable that beach water samples collected at times with little

369 to no wave action may underestimate the bacterial health risk later in the same day when

370 there are indeed stronger waves and disturbance of sediments by swimmers. Once re- 
371 suspended, bacteria may become further mobilized by general water flow and wind-

372 generated waves, leading to an increased potential for human ingestion (Droppo et al.

373 2009; Plach et al. 2011). The re-suspension of bacteria imparted by wave action (where

374 diurnal variation in waves at a beach may render a morning sample irrelevant to

375 afternoon conditions), together with the delay imparted by current methods used for

376 microbial sample analysis, pose a challenge for public health units. Predictive models

377 may therefore be an appropriate method for assessing the bacterial health risk during

378 times of turbulence and in storm events. Kinzelman et al. (2004) found wave height to be

379 the best predictor of $E$. coli concentration at beaches, and were able to derive a formula to

380 predict daily E. coli counts. Our observed relationship between wave action and re-

381 suspension of viable bacteria colonized in sediments, substantiate (reported) field studies

382 that have listed wave action as a potential mechanism of bacterial re-suspension in

383 surface waters (Hartz et al. 2008; McLellan and Salmore 2003). The correlation also

384 addresses the influence of shear force on bacterial transport in freshwater systems

385 (Yamahara et al. 2007).

386 Previous studies showing the persistence and/or growth of fecal indicators and

387 pathogens in beach sand suggested that an evaluation of bacteria in beach sand and

388 sediments in conjunction with a water sampling regimen contributes to a more successful

389 water quality monitoring program (Lee et al. 2006; Scopel et al. 2006). Our results in

390 Figure 5 showing no erosion of the test strain from the section of the core that did not

391 come into contact with swash, while the bottom section of this core indeed showed a

392 decrease in the numbers during wave events, suggest that cells were being drawn from

393 this area of the beach as backwash moved down the shoreline. Droppo et al. (2007) 
394 indicated that the cyclic shear stress resulting from wave action, referred to as

395 "pumping', may be accentuated by the presence of gas in pore spaces, which is a

396 probable explanation for the decreased cell numbers in the bottom core section of the far

397 upshore region.

398 Monitoring programs in the United States generally rely on one sample collected

399 at the shoreline (Scopel et al. 2006), while federal guidelines in Canada suggest that

400 sediment samples should be collected when there is evidence that bathing beaches could

401 be the source of waterborne disease (Health and Welfare Canada 1992). Amending these

402 guidelines to include a sampling regime that involves the routine examination of

403 sedimentary components, shoreline and near shore water, as well as regions up-shore of

404 the beach (i.e. considering the ecology of the related microorganisms) could be an

405 effective strategy for improving health risk assessment at public beaches.

406 The positive correlation $(\mathrm{r}>$ or $=0.80$ in all replicate trails $)$ between the

407 concentration of bacteria in the water column and TSS supports a suggestion by Droppo

408 et al. (2011) that turbidity may be an indicator of the microbiological quality of water.

409 Using samples collected from water and lake-bottom sediments along with additional

410 environmental data, Francy and Darner (1999) found that turbidity, antecedent rainfall,

411 volumes of wastewater-treatment plant overflows and metered outfalls, and wave height,

412 were statistically related to levels of E. coli at three public bathing beaches along Lake

413 Erie. However, Kinzelman et al. (2004) found that turbidity was not predictive of E. coli

414 levels, suggesting that specific environmental conditions (local phenomena) may

415 influence the predictive capabilities of the relationship. 
With the wave flume, sand grains are too large to remain in suspension at the

417 energy regimes studied, however, the flocculated cohesive fraction (clays, silts, and

418 organic matter) found within the biofilms forming in the interstitial voids of the sand

419 grains may be re-suspended and subsequently transport floc-associated bacteria within

420 the water column. Planktonic cells may also be released by erosion or dissociation from

421 flocs in suspension (Ghadakpour et al. 2014). The possible long-range transport of

422 mobilized microbial cohesive flocs is related to their high water content and low density

423 (often close to that of water). Typical quiescent settling velocities of flocs range from 0.1

424 to $4 \mathrm{~mm} \mathrm{~s}^{-1}$ (Droppo et al. 1997), suggesting that settling in a turbulent environment will

425 be even less. This was substantiated by the very slow rate of reduction in TSS during

426 wave periods. It is also probable that sand biofilms will form loosely associated micro-

427 colonies with relatively little cohesive sediment, which will be removed with increased

428 shear as floc (a phenomenon known as sloughing) (Stoodley et al. 2001; Ghadakpour et

429 al. 2014).

430 During the post wave period, larger particles settled towards the bed while cells

431 demonstrated an affinity for the smaller flocs remaining in suspension. This higher

432 number of cells associated with suspended flocs is likely due to a combination of

433 physical, chemical, and biological mechanisms, where cells actively attach to the floc

434 material when the kinetic energy of the system is reduced, and there is decreased

435 turbulence (time 330 to 450 minutes). Gerba and McLeod (1976) have shown that

436 bacteria preferentially attach to particles as they represent a source of protection from

437 environmental stress (e.g. energy conditions) and a source of food (i.e. DOC and POC).

438 Laboratory mesocosm experiments described by Garcia-Armisen and Servais (2009) 
439 found that water samples containing greater than $50 \mathrm{mg} / \mathrm{L}$ of suspended matter had a

440 relatively constant settling rate of particle-associated E. coli. In contrast, unattached $E$.

441 coli did not settle. This trend was observed in the unattached data of the current study

442 when waves were shut off. Lawrence et al. (1987) demonstrated that Pseudomonas

443 fluorescens cells were able to swim up-stream using flagellar-driven motility near $(2 \mu \mathrm{m})$

444 the surface of a slide culture chamber where the bulk liquid flow velocity was $200 \mu \mathrm{m} / \mathrm{s}$

445 compared to $10 \mathrm{~cm} / \mathrm{s}$ in the bulk phase. While the flow conditions were different, such a

446 result may suggest that the decrease in turbulence in the wave flume could allow for

447 similar flagellar-driven motility and thus possible preferential attachment to flocs.

448 Further, electrochemical conditions could also contribute to the observed

449 increased attachment of cells to the suspended flocs. The surface charge of particles is

450 known to influence particle-particle interactions. Reduction of the electrochemical double

451 layer through interactions between negative particles and positive cations can result in

452 attraction and/or flocculation, thus affecting the number of cells associated with settling

453 particles (Ongerth and Pecoraro 1996). In general, freshwater particles have a zeta

454 potential between -15 to $-30 \mathrm{mV}$ (Ongerth and Pecoraro 1996). The zeta potential of the

455 test strain used in this study was determined to be $-35 \mathrm{mV}$, therefore, aggregation of small

456 particles through the reduction of the electrochemical double layer may have provided

457 new niches for the attached cells, and contributed to the increased number of cells

458 observed under quiescent conditions.

459 A recent study using the test strain found that the average per cell $\mathrm{CO}_{2}$ production

460 rate (measure of metabolic activity) in biofilms formed by the test strain was significantly

461 higher for the cells in the outer regions at and near the biofilm-liquid interface than the 
462 cells positioned in the deeper regions. It was shown that when the shear susceptible cells

463 at the outer layers were removed, the newly exposed cells rapidly increased metabolic

464 activity in response to the higher nutrient and oxygen concentrations (Bester et al. 2010).

465 It is possible that bacteria in floc and biofilms partially depend on shear forces (such as

466 those related to wave energy) to maintain an optimum aggregate size to derive maximum

467 benefit (e.g. synergistic metabolism of complex nutrients, protection against

468 antimicrobial agents), while also maintaining flux of nutrients in - and metabolites out -

469 of the aggregates and thereby allowing the majority of the cells to remain active (Plach et

470 al. 2011).

471 In order to summarize the dynamic interaction of the physical environment with

472 the microbial community, a conceptual model for a wave environment has been modified

473 from the river scenario of Droppo et al. (2011) (Figure 6). In this model, bacterial cell

474 erosion occurs when the bed shear stress (imparted by waves) is greater than the critical

475 bed shear stress (energy at which bed sediment mobilizes (red decision box)). Eroded

476 cells may be either associated with flocs (silts, clays and viable and non-viable biological

477 material) or present in their planktonic phase. If the fluid shear imparted by waves is

478 greater than the suspended floc shear strength, which is the force that must be applied to

479 break up the floc, then floc-associated cells will dissociate (green decision box). It is the

480 dissociated cells (and those linked with smaller flocs) along with the planktonic phase

481 cells that remain in suspension due to turbulence or natural buoyancy. Bacteria attached

482 to larger flocs are removed from the water column with the downward flux of larger

483 particles. Planktonic bacteria may undergo passive reattachment via the physical

484 processes of flocculation or scavenging during settling, or active reattachment given the 
485 flocs representing a desirable surface to colonize (i.e. floc may represent a more effective 486 source of organic matter for consumption/energy). This concentration effect of planktonic 487 bacteria was particularly observed in experiments when turbulence was removed from the 488 system. As flocs settle, if the bed shear is not greater than the floc shear strength, then 489 larger flocs are deposited on the sediment bed and this leads to consolidation and 490 incorporation in biofilms (blue decision box). Alternatively, if the bed shear is greater

491 than the floc shear strength, flocs will break up with cells and sediment being transported 492 further within the system. This conceptual model highlights the transient nature of floc

493 transport in freshwater systems and demonstrates the dynamic nature of cell-floc 494 associations. Considering the benefits for cells to be incorporated in microbial flocs, it 495 also highlights the potential importance of floc as a vector for bacterial transport in lake 496 systems.

497 Future work utilizing a flow cell /shear cell to examine flocculation and break-up 498 could provide insight to the potential release of floc-associated Pseudomonas sp. strain 499 CTO7::gfp-2 under conditions of increasing shear. Differentially-labeled test strains may 500 also be useful to assess the degree of mixing of sediment-associated and suspended 501 bacteria with wave action.

\section{Acknowledgements}

504 This research was supported by contributions from the National Science and 505 Engineering Research Council of Canada (NSERC), Ryerson University, Environment 506 Canada and the Canada Research Chairs Program. Technical assistance was provided by 
507 Christina Jaskot, Brian Trapp, Evan Ronan, Claire Alexia Lane, Kristen King, and

508 Katrina Bernal. Karen Quinto assisted with the drafting of Figure 6.

509

$510 \quad$ References

511 Alm, E.W., Burke, J., and Hagan, E. 2006. Persistence and potential growth of the fecal

512 indicator bacteria, Escherichia coli, in shoreline sand at Lake Huron. J .Great Lakes Res.

513 32: 401-405.

514 Bester, E., Edwards, E., and Wolfaardt, G.M. 2009. Planktonic cell yield is linked to

515 biofilm development. Can. J. Microbiol. 55: 1195-1206.

516 Bester, E., Kroukamp, O., Wolfaardt, G.M., Boonzaaier, L., and Liss, S.N. 2010.

517 Metabolic differentiation in biofilms as indicated by carbon dioxide production rates.

518 Appl. Environ. Microbiol. 76: 1189-1197.

519 Bonilla, T.D., Nowosielski, K., Cuvelier, M., Hartz, A., Green, M., Esiobu, N.,

520 McCorquodale, D.S., Fleisher, J.M., and Rogerson, A. 2007. Prevalence and distribution

521 of fecal indicator organisms in South Florida beach sand and preliminary assessment of

522 health effects associated with beach sand exposure. Mar. Pollut. Bull. 54: 1472-1482.

523 Brookes, J.D., Antenucci, J., Hipsey, M., Burch, M.D., Ashbolt, N.J., and Ferguson, C.

524 2004. Fate and transport of pathogens in lakes and reservoirs. Environ. Int. 30: 741-759. 
525 City of Toronto 2009. Great City, Great Beaches: Toronto Beaches Plan; 08-R-43-630;

526 City of Toronto: Toronto, ON, 2009;

527 www.toronto.ca/legdocs/mmis/2009/ex/bgrd/backgroundfile-18573.pdf

528 Cogan, N.G., Gunn J.S., and Wozniak, D.J. 2011. Biofilms and infectious diseases:

529 biology to mathematics and back again. FEMS Microbiol. Lett. 322:1-7.

530 Craun, G.F., Calderon, R.L., and Craun, M.F. 2005. Outbreaks associated with

531 recreational water in the United States. Int. J. Environ. Health Res. 15: 243-262.

532 Dette, H.H., Larson, M., Murphy, J., Newe, J., Peters, K., Reniers, A., and Steetzel, H.

533 2002. Application of prototype flume tests for beach nourishment assessment. Coast.

534 Eng. 47: 137-177.

535 Droppo, I.G., Leppard, G.G., Flannigan, D.T., and Liss, S.N. 1997. The freshwater floc: a

536 functional relationship of water and organic and inorganic floc constituents affecting

537 suspended sediment properties. Wat. Air Soil Pollut. 99: 43-53.

538 Droppo, I.G., Ross, N., Skafel, M., and Liss, S. 2007. Biostabilization of cohesive

539 sediment beds in a freshwater wave dominated environment. Limnol. Oceanogr. 52: 577 -

$540 \quad 589$.

541 Droppo, I.G., Liss, S.N., Williams, D., Nelson, T., Jaskot, C., and Trapp, B. 2009.

542 Dynamic existence of waterborne pathogens within river sediment compartments:

543 implications for water quality regulatory affairs. Env. Sci. Technol. 43: 1737-1743. 
545 Droppo, I.G., Krishnappan, B.G., Liss, S.N., Marvin, C. and Biberhofer, H. 2011.

546 Modelling sediment-microbial dynamics in the South Nation River, Ontario, Canada:

547 towards the prediction of aquatic and human health risk. Wat. Res. 45: 3797-3809.

548 Francy, D.S., and Darner, R.A. 1999. Factors affecting Escherichia coli concentrations at

549 Lake Erie public bathing beaches, IAGLR '99. A-33.

550 Garcia-Armisen, T., and Servais, P. 2009. Partitioning of particle-associated E. coli in

551 river waters. Wat. Environ. Res. 81: 21-28.

552 Gerba, C.P., and McLeod, J.S. 1976. Effect of sediments on the survival of Escherichia

553 coli in marine waters. Appl. Environ. Microbiol. 32: 114-120.

554 Gerbersdorf, S.U., and Wierpecht, S. 2014. Biostabilization of cohesive sediments:

555 revisiting the role of abiotic conditions, physiology and diversity of microbes, polymeric

556 secretion, and biofilm architecture. Geobiology, DOI: 10.1111/gbi.12115

557 Ghadakpour, M., Bester, E., Liss, S.N., Gardam, M., Droppo, I.G., Hota, S., and

558 Wolfaardt, G.M. 2014. Integration and proliferation of Pseudomonas aeruginosa PAO1

559 in multispecies biofilms. Microb. Ecol. 68: 121-131.

560 Hartz, A., Cuvelier, M., Nowosielski, K., Bonilla, T.D., Green, M., Esiobu, N.,

561 McCorquodale, D.S., and Rogerson, A. 2008. Survival potential of Escherichia coli and

562 enterococci in subtropical beach sand: implications for water quality managers. J.

563 Environ. Qual. 37: 898-905.

564

https://mc06.manuscriptcentral.com/cjm-pubs 
565 Health and Welfare Canada 1992. Guidelines for Canadian recreational water quality;

566 H49-70/1991E; Health and Welfare Canada, Ottawa, ON, 1992;

567 http://publications.gc.ca/site/eng/14774/publication.html

568 Ishii, S., Hansen, D.L., Hicks, R.E., and Sadowsky, M.J. 2007. Beach sand and sediments

569 are temporal sinks and sources of Escherichia coli in Lake Superior. Env. Sci. Technol.

570 41: 2203-2209.

571 Ji, Z. 2008. Hydrodynamics and water quality: modeling rivers, lakes, and estuaries;

572 Wiley-Interscience: Hoboken, N.J.

573 Kinzelman, J., McLellan, S.L., Daniels, A.D., Cashin, S., Singh, A., Gradus, S., and

574 Bagley, R. 2004. Non-point source pollution: Determination of replication versus

575 persistence of Escherichia coli in surface water and sediments with correlation of levels

576 to readily measurable environmental parameters. J. Wat. Health. 2: 103-114.

577 Kroukamp, O. and Wolfaardt, G.M. 2009. $\mathrm{CO}_{2}$ production as an indicator of biofilm

578 metabolism. Appl. Environ. Microbiol. 75: 4391-4397.

579 Lawrence, J.R., Delaquid, P.J., Korber, D.R., and Caldwell, D.E. 1987. Behavior of

580 Pseudomonas fluorescens within the hydrodynamic boundary layers of surface

581 microenvironments. Microb. Ecol. 14: 1-14.

582 Lee, C.M., Lin, T.Y., Lin, C.C., Kohbodi, G.A., Bhattl, A., Lee, R., and Jay, J.A. 2006.

583 Persistence of fecal indicator bacteria in Santa Monica Bay beach sediments. Wat. Res.

584 40: 2593-2602. 
585 Mueller-Spitz, S.R., Stewart, L.B., Klump, J.V., and McLellan, S.L. 2010. Freshwater

586 suspended sediments and sewage are reservoirs for enterotoxin-positive Clostridium

587 perfringens. Appl. Environ. Microbiol. 76: 5556-5562.

588 McLellan, S.L. and Salmore, A.K. 2003. Evidence for localized bacterial loading as the 589 cause of chronic beach closings in a freshwater marina. Water Res. 37: 2700-2708.

590 Ongerth, J.E. and Pecoraro, J.P. 1996. Electrophoretic mobility of Cryptosporidium

591 oocysts and Giardia cysts. J. Environ. Eng. 123: 228-231.

592 Perdek, J., Arnone, R. D., Stinson, K. and Tuccillo, T.E. 2003. Managing urban

593 watershed pathogen contaminantion. U.S. Environmental Protection Agency,

594 Washington, DC, EPA/600/R-03/111, 2003.

595 Petersen, T.M. Rifai, H.S. Suarez, M.P. and Stein, A.R. 2005. Bacteria loads from point

596 and nonpoint sources in an urban watershed. J. Environ. Eng. 131: 1414-1425.

597 Plach, J.M., Elliott, A.V.C., Droppo, I.G., and Warren, L.A. 2011. Physical and

598 ecological controls on freshwater floc trace metal dynamics. Env. Sci. Technol. 45: 2157-

5992164.

600 Purevdorj-Gage, B., Costerton, W.J., and Stoodley, P. 2005. Phenotypic differentiation

601 and seeding dispersal in non-mucoid and mucoid Pseudomonas aeruginosa biofilms.

602 Microbiology-Sgm. 151:1569-1576. 
603 Sauer, K., Camper, A.K., Ehrlich, G.D., Costerton, J.W., and Davies, D.G. 2002.

604 Pseudomonas aeruginosa displays multiple phenotypes during development as a biofilm.

605 J. Bacteriol. 184: 1140-1154.

606 Scopel, C.O., Harris, J., and McLellan, S.L. 2006. Influence of nearshore water dynamics

607 and pollution sources on beach monitoring outcomes at two adjacent Lake Michigan

608 beaches. J. Great Lakes Res. 32: 543-552.

609 Searcy, K.E., Packman, A.I., Atwill, E.R., and Harter, T. 2005. Association of

610 Cryptosporidium parvum with suspended particles: Impact on oocyst sedimentation.

611 Appl. Environ. Microbiol. 71: 1072-1078.

612 Stoodley, P., Wilson, S., Hall-Stoodley, L., Boyle, J.D., Lappin-Scott, H.M., and

613 Costerton, J.W. 2001. Growth and detachment of cell clusters from mature mixed-species

614 biofilms. Appl. Environ. Microbiol. 67: 5608-5613.

615 Tolker-Nielsen, T., Brinch, U.C., Ragas, P.C., Andersen, J.B., Jacobsen, C.S., and Molin,

616 S. 2000. Development and dynamics of Pseudomonas sp. biofilms. J Bacteriol. 182:

$617 \quad 6482-6489$

618 Turker, U., and Kabdash, M.S. 2006. The effects of sediment characteristics and wave

619 height on shape-parameter for representing equilibrium beach profiles. J. Ocean. Eng. 33:

$620 \quad 281-291$.

621 Whitman, R.L., Shively, D.A., Pawlik, H., Nevers, M.B., and Byappanahalli, M.N. 2003.

622 Occurrence of Escherichia coli and enterococci in Cladophora (Chlorophyta) in 
623 nearshore water and beach sand of Lake Michigan. Appl. Environ. Microbiol. 69: 4714-

6244719.

625 Wolfaardt, G.M., Hendry, M.J., Birkham, T., Bressel, A., Gardner, M.N., Sousa, A.J.,

626 Korber, D.R., and Pilaski, M. 2008. Microbial response to environmental gradients in a

627 ceramic-based diffusion system. Biotechnol. Bioeng. 100: 141-149.

628 Wu, J., Rees, P., Storrer, S., Alderisio, K., and Dorner, S. 2009. Fate and transport

629 modeling of potential pathogens: the contribution from sediments. JAWRA. 45: 35-44.

630 Yamahara, K.M., Layton, B.A., Santoro, A.E., and Boehm, A.B. 2007. Beach sands

631 along the California coast are diffuse sources of fecal bacteria to coastal waters. Env. Sci.

632 Technol. 41: 4515-4521. 
634 Table 1 Partitioning of free-floating and floc-associated cells before, during and after 635 operating the flume at $0.60 \mathrm{~N} / \mathrm{s}$.

\begin{tabular}{|c|c|c|c|c|c|c|c|}
\hline $\begin{array}{c}\text { Wave } \\
\text { Energy } \\
\text { Flux } \\
(\mathrm{N} / \mathrm{s})\end{array}$ & $\begin{array}{l}\text { Time } \\
(\mathrm{min})\end{array}$ & $\begin{array}{c}\text { Median } \\
\text { Floc ESD }{ }^{1} \\
(\mu \mathrm{m})\end{array}$ & $\begin{array}{c}\text { Total } \\
\text { Suspended } \\
\text { Solids } \\
(\mathrm{mg} / \mathrm{L})\end{array}$ & $\begin{array}{c}\text { Free- } \\
\text { Floating } \\
\text { Cells/ } 50 \\
\text { mL }\end{array}$ & $\begin{array}{c}\text { Floc- } \\
\text { Associated } \\
\text { Cells/ } 50 \\
\text { mL }\end{array}$ & $\begin{array}{l}\% \text { Cells } \\
\text { in floc }\end{array}$ & $\begin{array}{c}\text { Floc- } \\
\text { Associated } \\
\text { Cells } \\
\text { (CFU/ mg } \\
\text { floc) }\end{array}$ \\
\hline 0 & 30 & $\mathrm{nd}^{3}$ & $10 \pm 1$ & $6.20 \times 10^{2}$ & $1.29 \times 10^{4}$ & 95 & $2.58 \times 10^{4}$ \\
\hline 0 & 60 & 14.75 & $13 \pm 2$ & $1.35 \times 10^{3}$ & $1.02 \times 10^{4}$ & 88 & $1.57 \times 10^{4}$ \\
\hline 0.60 & 90 & 17.07 & $56 \pm 2$ & $4.30 \times 10^{3}$ & $2.71 \times 10^{5}$ & 98 & $9.68 \times 10^{4}$ \\
\hline 0.60 & 120 & 15.09 & $67 \pm 1$ & $3.80 \times 10^{3}$ & $5.40 \times 10^{4}$ & 93 & $1.61 \times 10^{4}$ \\
\hline 0.60 & 150 & 13.56 & $61 \pm 2$ & $1.80 \times 10^{3}$ & $8.10 \times 10^{4}$ & 98 & $2.66 \times 10^{4}$ \\
\hline 0.60 & 180 & 12.42 & $56 \pm 1$ & $2.10 \times 10^{3}$ & $5.50 \times 10^{4}$ & 96 & $1.96 \times 10^{4}$ \\
\hline 0.60 & 210 & 11.33 & $55 \pm 2$ & $2.40 \times 10^{3}$ & $7.80 \times 10^{4}$ & 97 & $2.84 \times 10^{4}$ \\
\hline 0.60 & 240 & 8.56 & $44 \pm 2$ & $1.90 \times 10^{3}$ & $9.30 \times 10^{4}$ & 98 & $4.23 \times 10^{4}$ \\
\hline 0.60 & 270 & 7.93 & $36 \pm 1$ & $3.50 \times 10^{3}$ & $9.00 \times 10^{4}$ & 96 & $5.00 \times 10^{4}$ \\
\hline 0.60 & 300 & 5.36 & $20 \pm 1$ & $2.40 \times 10^{3}$ & $6.60 \times 10^{4}$ & 96 & $6.60 \times 10^{4}$ \\
\hline 0 & 330 & 4.63 & $16 \pm 2$ & $1.50 \times 10^{3}$ & $1.14 \times 10^{5}$ & 99 & $1.43 \times 10^{5}$ \\
\hline 0 & 360 & 3.24 & $8 \pm 1$ & $2.00 \times 10^{3}$ & $1.51 \times 10^{5}$ & 99 & $3.78 \times 10^{5}$ \\
\hline 0 & 390 & 3.05 & $16 \pm 9$ & $1.20 \times 10^{3}$ & $5.90 \times 10^{4}$ & 98 & $7.38 \times 10^{4}$ \\
\hline 0 & 420 & 3.11 & $23 \pm 4$ & $6.90 \times 10^{3}$ & $2.28 \times 10^{5}$ & 97 & $1.98 \times 10^{5}$ \\
\hline 0 & 450 & 2.66 & $21 \pm 7$ & $3.80 \times 10^{3}$ & $1.31 \times 10^{5}$ & 97 & $1.25 \times 10^{5}$ \\
\hline
\end{tabular}

636 1) ESD: equivalent spherical diameter

637 2) $n=2$ for total suspended solids ( $\pm=$ standard deviation)

638 3) nd: no data 
640 
641

642 Table 2 Partitioning of free-floating and floc-associated cells before, during and after 643 operating flume at $5.35 \mathrm{~N} / \mathrm{s}$.

\begin{tabular}{|c|c|c|c|c|c|c|c|}
\hline $\begin{array}{l}\text { Wave } \\
\text { Energy } \\
\text { Flux } \\
(\mathrm{N} / \mathrm{s})\end{array}$ & $\begin{array}{l}\text { Time } \\
(\mathrm{min})\end{array}$ & $\begin{array}{l}\text { Median } \\
\text { Floc ESD } \\
\quad(\mu \mathrm{m})\end{array}$ & $\begin{array}{c}\text { Total } \\
\text { Suspended } \\
\text { Solids } \\
(\mathrm{mg} / \mathrm{L})\end{array}$ & $\begin{array}{c}\text { Free- } \\
\text { Floating } \\
\text { Cells/ } 50 \\
\mathrm{~mL}\end{array}$ & $\begin{array}{c}\text { Floc- } \\
\text { Associated } \\
\text { Cells/ } 50 \\
\mathrm{~mL}\end{array}$ & $\begin{array}{l}\% \text { Cells in } \\
\text { floc }\end{array}$ & $\begin{array}{c}\text { Floc- } \\
\text { Associated } \\
\text { Cells } \\
\text { (CFU/ mg } \\
\text { floc) }\end{array}$ \\
\hline 0 & 30 & $\mathrm{Nd}$ & $2 \pm 1$ & $7.70 \times 10^{1}$ & $2.70 \times 10^{3}$ & 97 & $2.70 \times 10^{4}$ \\
\hline 0 & 60 & 15.19 & $2 \pm 1$ & $2.30 \times 10^{1}$ & $3.60 \times 10^{2}$ & 94 & $3.60 \times 10^{3}$ \\
\hline 5.35 & 90 & 11.99 & $117 \pm 3$ & $1.60 \times 10^{2}$ & $1.40 \times 10^{4}$ & 99 & $2.39 \times 10^{3}$ \\
\hline 5.35 & 120 & 11.03 & $130 \pm 4$ & $1.00 \times 10^{2}$ & $1.10 \times 10^{4}$ & 99 & $1.69 \times 10^{3}$ \\
\hline 5.35 & 150 & 10.53 & $132 \pm 7$ & $4.00 \times 10^{1}$ & $1.80 \times 10^{4}$ & 99.9 & $2.73 \times 10^{3}$ \\
\hline 5.35 & 180 & 10.37 & $125 \pm 1$ & $1.60 \times 10^{2}$ & $1.70 \times 10^{4}$ & 99 & $2.72 \times 10^{3}$ \\
\hline 5.35 & 210 & 10.83 & $143 \pm 1$ & $1.10 \times 10^{2}$ & $1.10 \times 10^{4}$ & 99 & $1.54 \times 10^{3}$ \\
\hline 5.35 & 240 & 10.76 & $146 \pm 3$ & $6.00 \times 10^{1}$ & $3.60 \times 10^{4}$ & 99.9 & $4.93 \times 10^{3}$ \\
\hline 5.35 & 270 & 10.86 & $145 \pm 1$ & $2.00 \times 10^{1}$ & $9.00 \times 10^{3}$ & 99.9 & $1.24 \times 10^{3}$ \\
\hline 5.35 & 300 & 10.50 & $153 \pm 1$ & $8.00 \times 10^{1}$ & $1.00 \times 10^{4}$ & 99 & $1.31 \times 10^{3}$ \\
\hline 0 & 330 & 10.21 & $120 \pm 8$ & $1.50 \times 10^{1}$ & $5.00 \times 10^{4}$ & 99.9 & $8.33 \times 10^{3}$ \\
\hline 0 & 360 & 9.43 & $92 \pm 2$ & $1.60 \times 10^{2}$ & $4.70 \times 10^{5}$ & 99.9 & $1.02 \times 10^{5}$ \\
\hline 0 & 390 & 8.97 & $78 \pm 8$ & $1.10 \times 10^{2}$ & $8.80 \times 10^{5}$ & 99.9 & $2.26 \times 10^{5}$ \\
\hline 0 & 420 & 8.26 & $55 \pm 11$ & $1.70 \times 10^{2}$ & $4.50 \times 10^{5}$ & 99.9 & $1.64 \times 10^{5}$ \\
\hline 0 & 450 & 7.75 & $42 \pm 6$ & $1.20 \times 10^{2}$ & $6.50 \times 10^{5}$ & 99.9 & $3.10 \times 10^{5}$ \\
\hline
\end{tabular}

644 1) ESD: equivalent spherical diameter

645 2) $n=2$ for total suspended solids (standard deviation)

646 3) nd: no data

647 
648 Table 3 Pearson correlation table of wave energy to numbers of the test strain and total 649 suspended solids $(\mathrm{n}=$ minimum 3 measurements)

$\begin{array}{ccc}\text { Wave Energy (N/s) } & \text { CFU r } & \text { TSS r } \\ 0 & 0.15 & 0.80 \\ & 0.03 & 0 \\ & -- & -- \\ 0.60 & 0.32 & 0.17 \\ & 0.77 & \\ & 0.97 & 0.89 \\ & 0.04 & 0.89 \\ & 0.91 & 0.93 \\ & & \\ & 0.61 & 0.97 \\ & 0.85 & 0.97 \\ & 0.00 & 0.60 \\ & 0.02 & 0.17 \\ & & \\ & 0.91 & 0.65 \\ & 0.11 & 0.74 \\ & 0.62 & 0.69 \\ & 0.91 & 0.78\end{array}$

650

651 


\section{Titles and legends to figures}

656 Figure 1: Schematic of wave flume. WETM: wave energy transmitting membrane. Not 657 to scale.

659 Figure 2 A) Schematic of core sampling strategy used in shear experiments. Transect 1

660 (T1) refers to below water line, and was roughly the wave breaking zone. T2 refers to the 661 swash zone; the area where the shoreline moves back and forth as waves meet the shore.

662 T3 is at the air-water-sediment interface, which was the furthest area where water

663 travelled up the beach and varied with wave energy, as higher wave energies pushed

664 water further up the beach. T4 was the far upshore region of the beach beyond the

665 furthest point of wave movement. B) Schematic of core sampling strategy to study

666 transport of the test strain in sand. T1 and T2 were below the water line. T3 was at the

667 water line, and T4 and T5 were above the water line. All transects were separated by a

668 distance of approximately $25 \mathrm{~cm}$. WETM: wave energy transmitting membrane.

670 Figure 3A). Tracking the movement of Pseudomonas sp. strain CTO7::gfp-2 from the

671 water into the sand with sand cores taken along five beach transects (see Figure 2B).

672 Transects 1 and 2 were below the water line. Transect 3 was at the water line, and

673 transects 4 and 5 were above the water line and water table. All transects were separated

674 by a distance of approximately $25 \mathrm{~cm}$. B) CLSM image of a 72 hour sand biofilm formed

675 in interstitial voids, showing that the biofilms contain both indigenous bacteria (bright

676 fluorescence) and the green test strain. 
678 Figure 4 A-D. Cumulative effect of increasing wave energy flux on total suspended 679 solids (TSS) and levels of Pseudomonas sp. strain CTO7::gfp-2 in water. A, B, C, D

680 represent four trials. The $\mathrm{d}_{50}$ value for each wave energy flux is reported above the solid 681 black line. Counts of test strain and total suspended solids represent average values $(n=3$ 682 and $\mathrm{n}=2$, respectively).

684 Figure 5. Enumeration of Pseudomonas sp. strain CTO7::gfp-2 from sand cores taken 685 along four beach transects (trial 1;). Transect 1 (T1) refers to below water line, and was 686 roughly the wave breaking zone. B) Transect 2 (T2) refers to the swash zone, which was 687 the area where the shoreline moves back and forth as waves meet the shore. C) Transect 3 688 (T3) characterized the air-water-sediment interface, and was the furthest area where water 689 travelled up the beach when waves were run. The exact location of transect 3 varied with 690 wave energy, as higher wave energies pushed water further up the beach. Bottom, middle 691 and top refer to the enumeration of the test organism from $6 \mathrm{~cm}, 4 \mathrm{~cm}$ and $2 \mathrm{~cm}$ below the 692 surface of the sediment bed. D) Transect 4 was the far upshore region of the beach

693 beyond the furthest point of wave movement. Counts of the test organism represent 694 average $(n=2)$.

695

696 Figure 6. Conceptual model of sediment-microbial dynamics in freshwater beach 697 systems influenced by wave energy. 
Figure 1

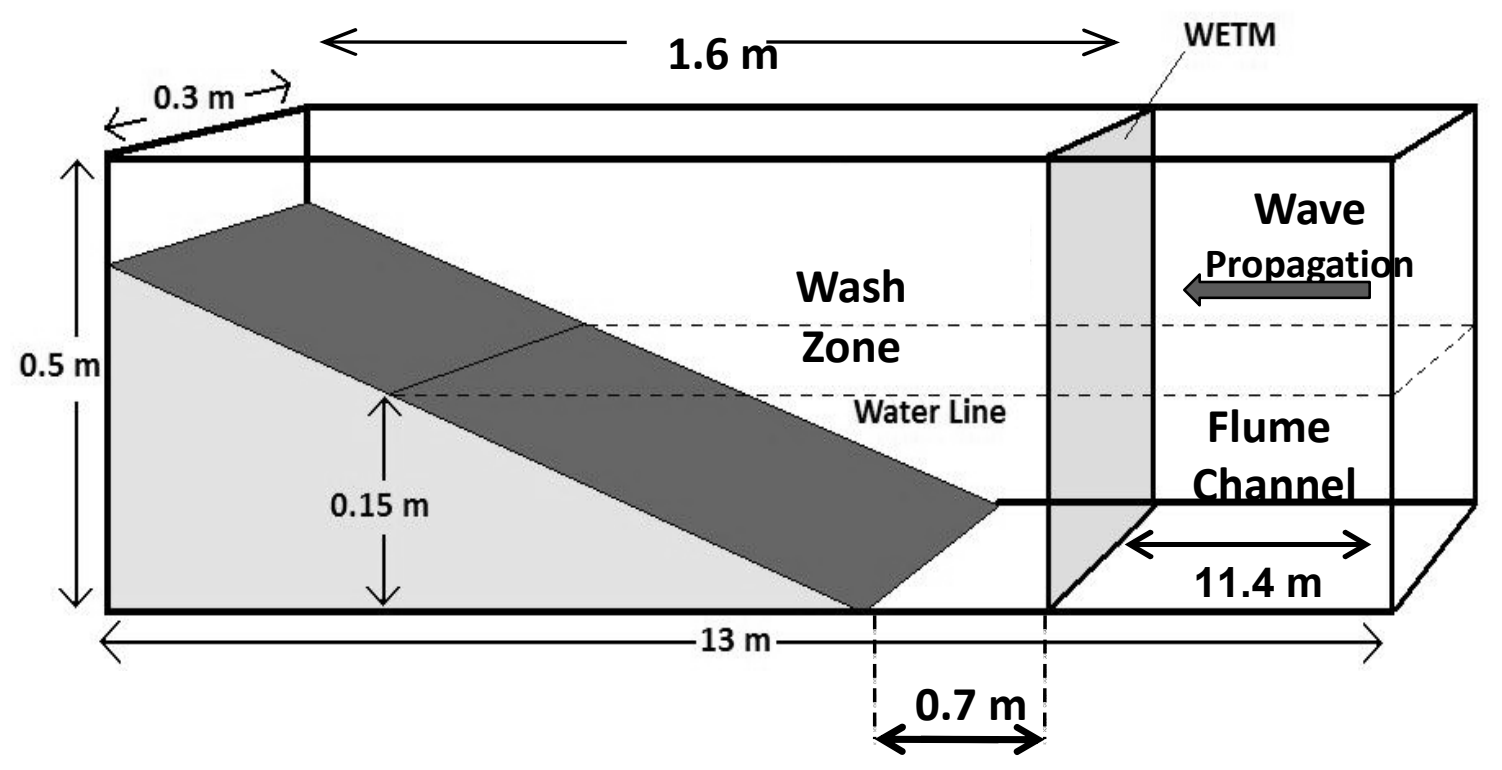


Figure 2

A

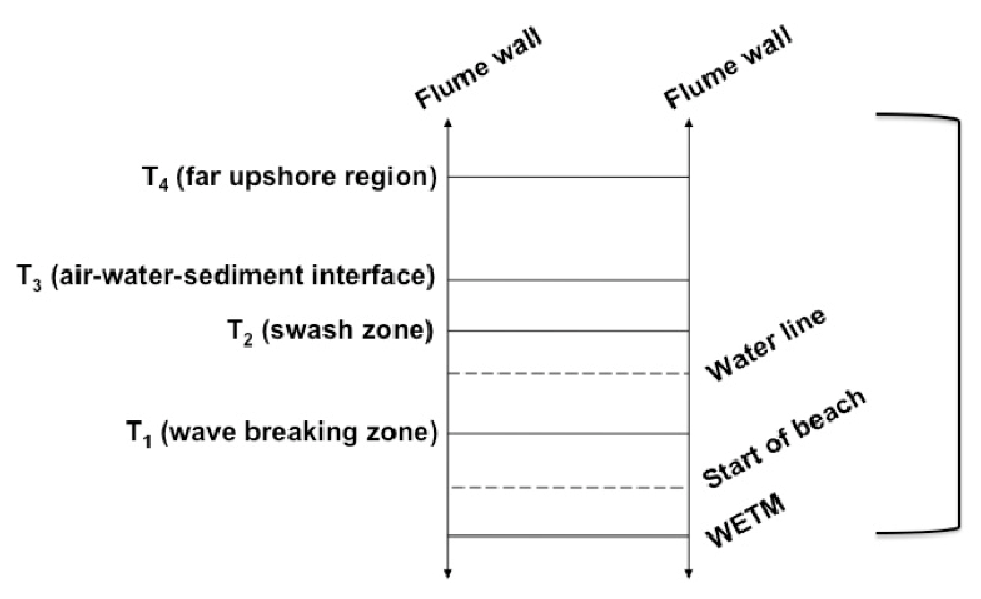

B

Wash zone

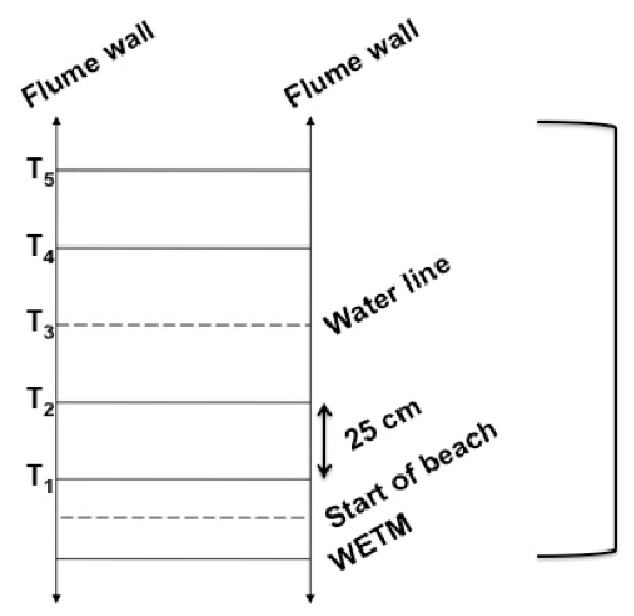

Wash

zone 
Figure $3 \mathrm{~A}$ )

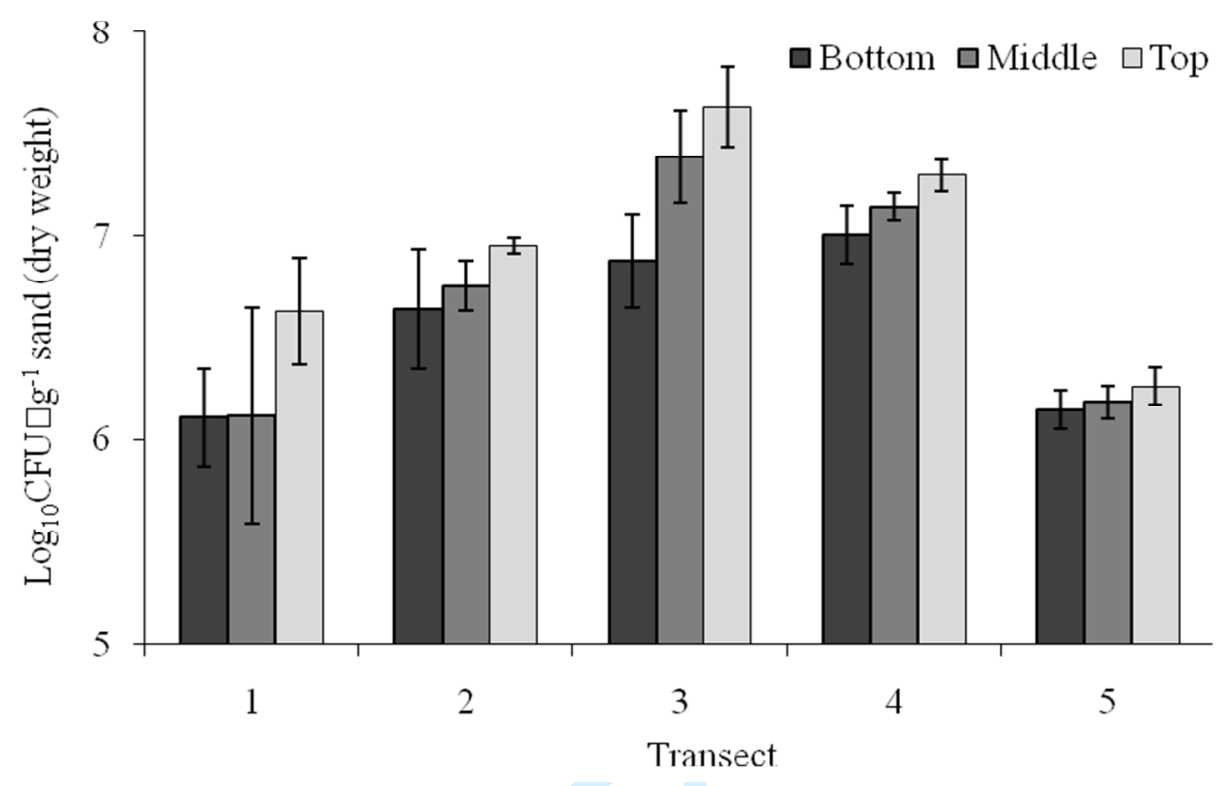

Figure 3 B)

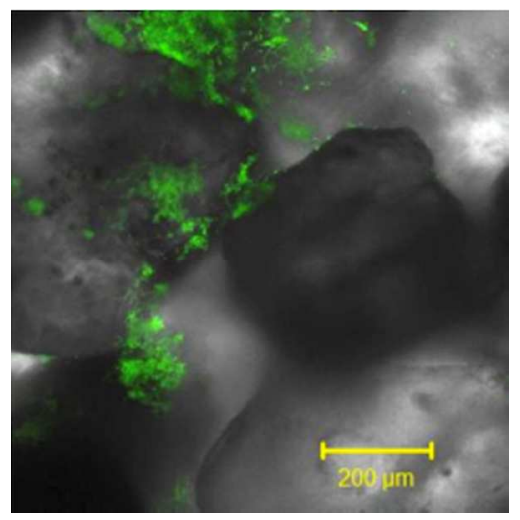


Figure 4
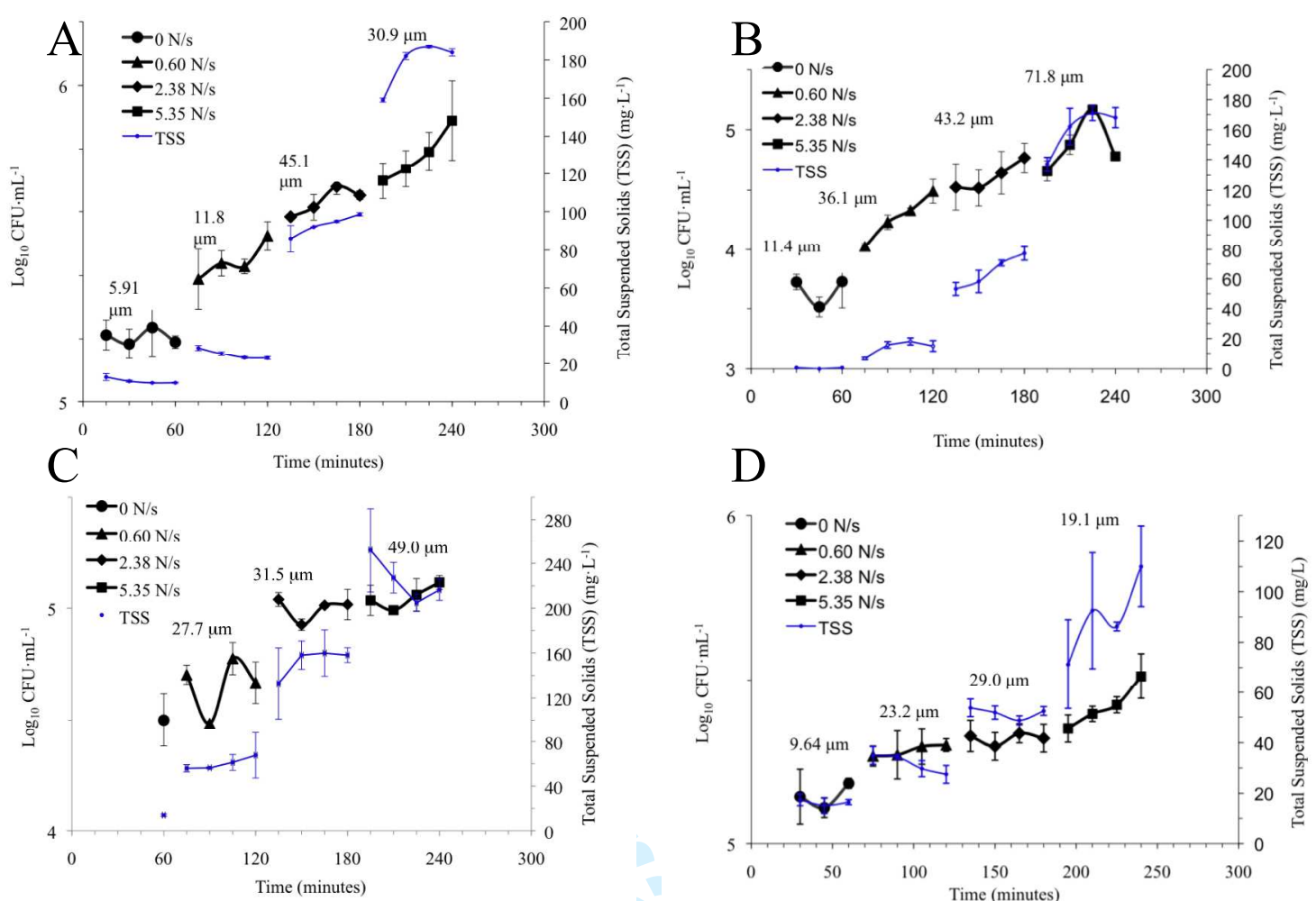
Figure 5

A) Bottom

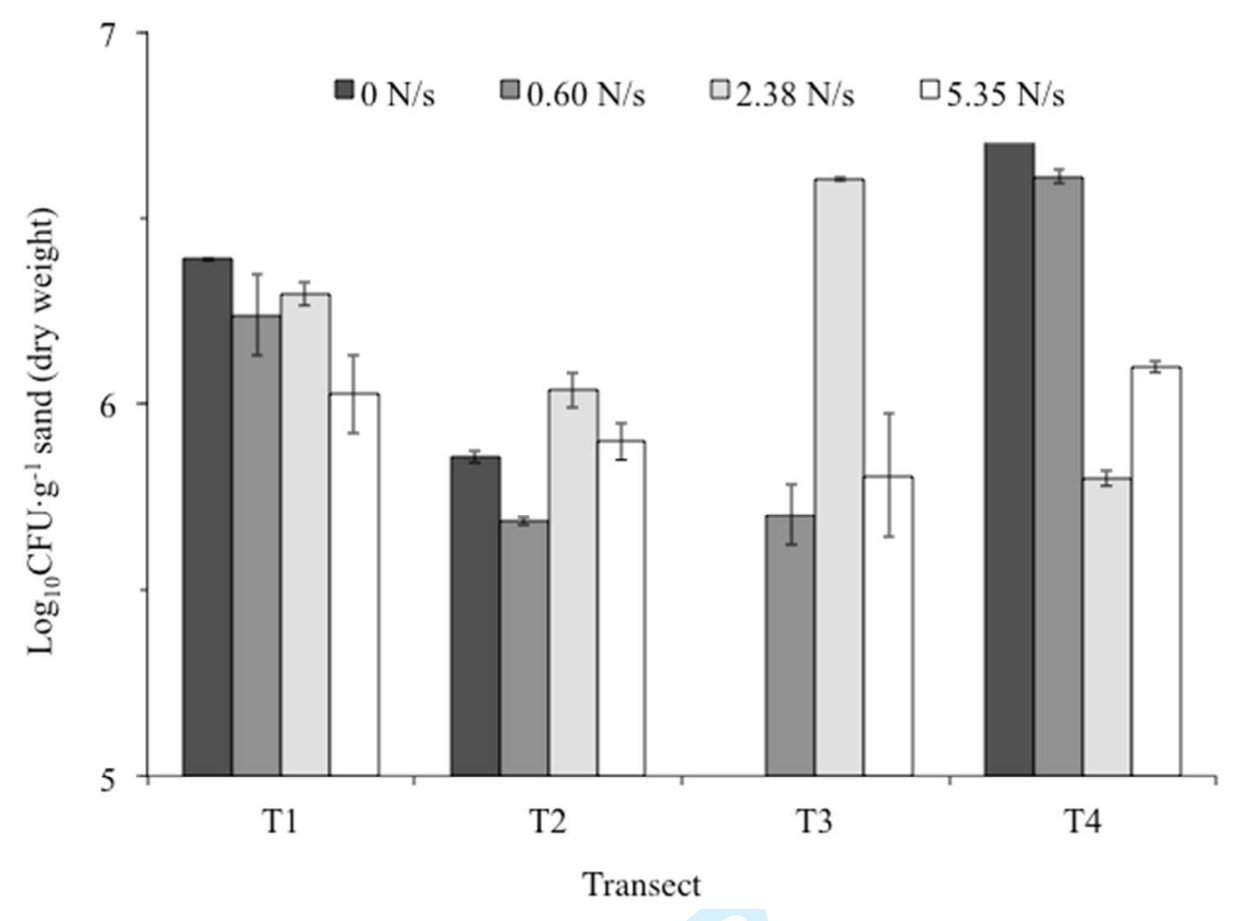

B) Middle

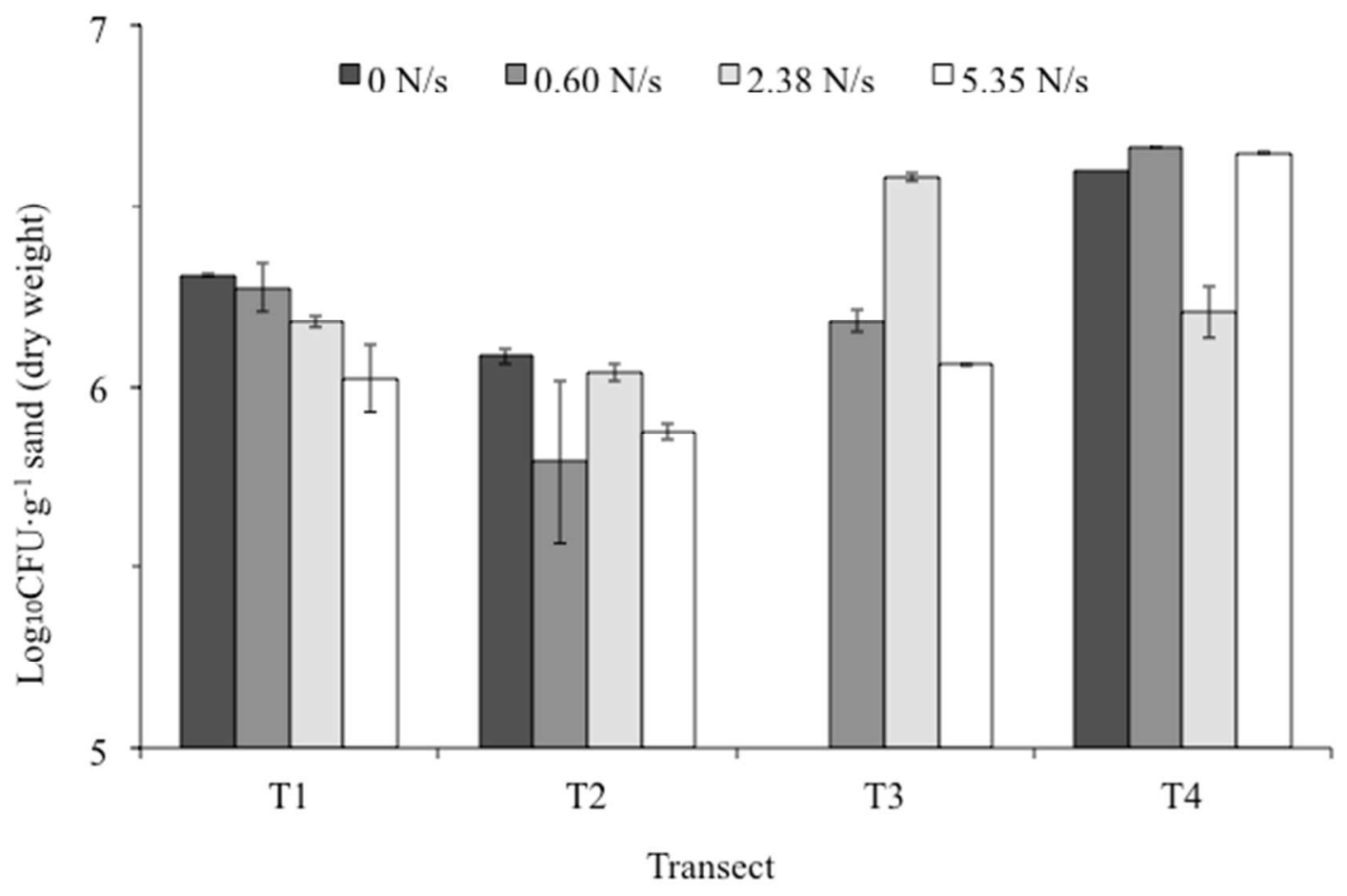


C) Top

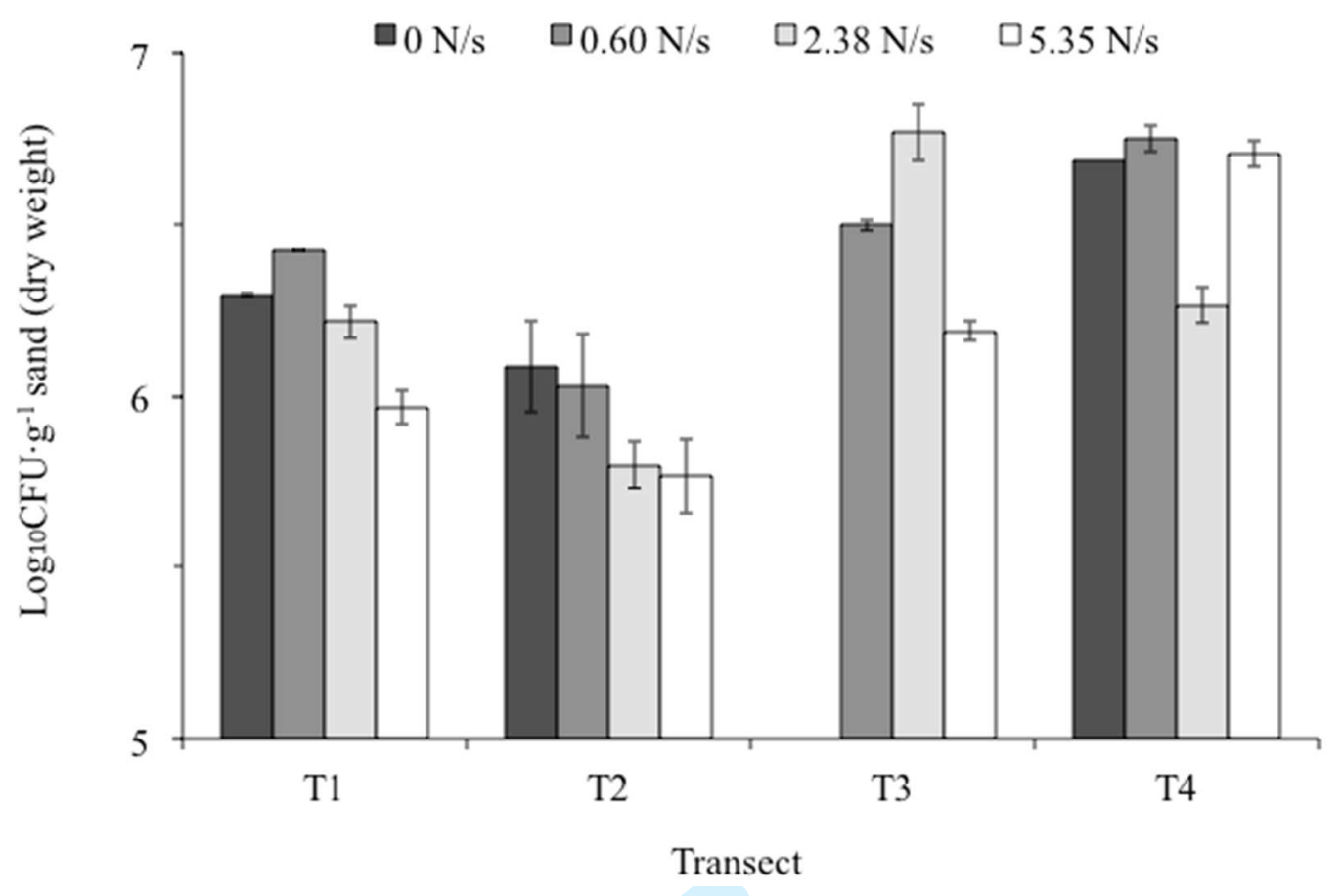

https://mc06.manuscriptcentral.com/cjm-pubs 


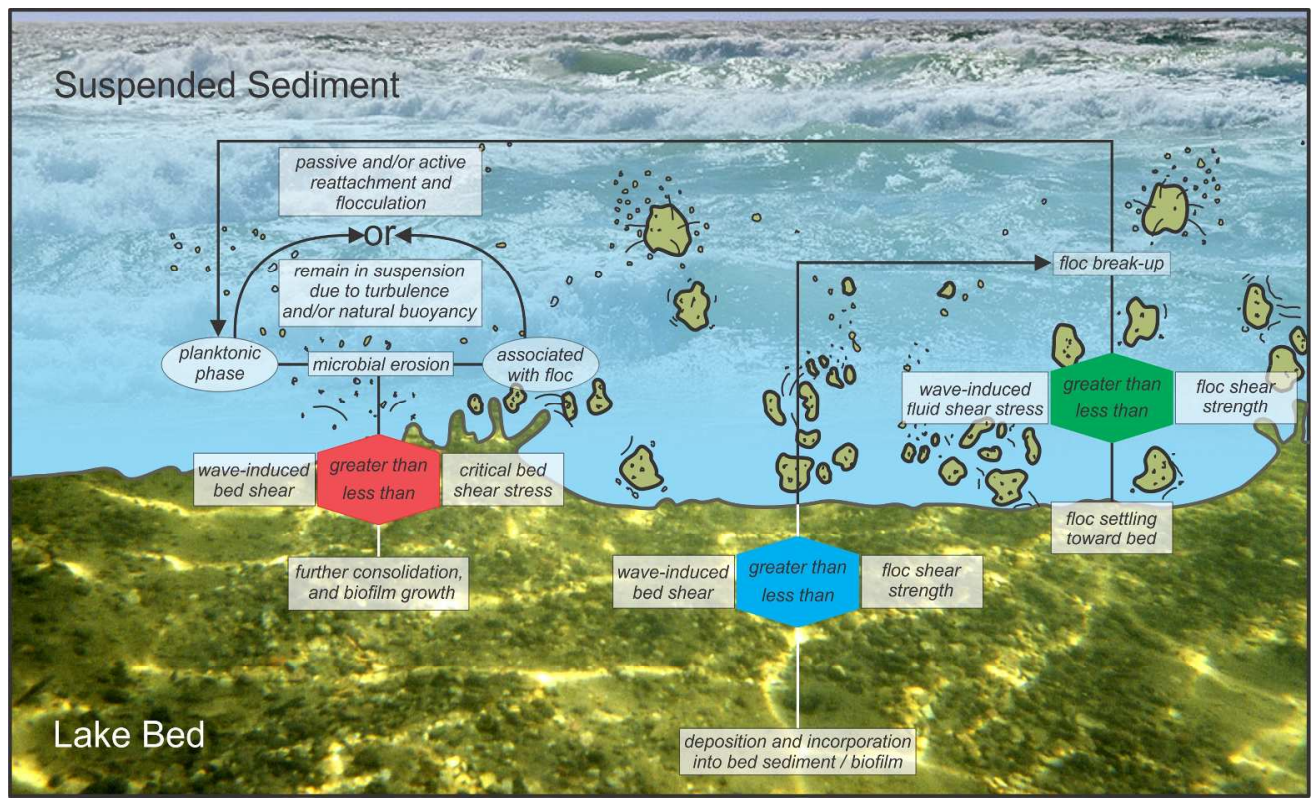

Figure 6. Conceptual model of sediment-microbial dynamics in freshwater beach systems influenced by wave energy. $249 \times 151 \mathrm{~mm}(300 \times 300 \mathrm{DPI})$ 